Pesq. Vet. Bras. 35(12):941-946, dezembro 2015 DOI: $10.1590 / \mathrm{S} 0100-736 \mathrm{X} 2015001200001$

\title{
Gastrointestinal parasites of swine raised in different management systems in the State of Rio de Janeiro, Brazil ${ }^{1}$
}

\author{
Alynne S. Barbosa ${ }^{2 *}$, Otilio M.P. Bastos ${ }^{3}$, Laís V. Dib², Mayara P. de Siqueira ${ }^{3}$, \\ Matheus L. Cardozo ${ }^{3}$, Luiz Claudio Ferreira ${ }^{4}$, William T. Chaves ${ }^{2}$, Ana Beatriz M. \\ Fonseca $^{5}$, Claudia M.A. Uchôa ${ }^{3}$ and Maria Regina R. Amendoeira ${ }^{2}$
}

\begin{abstract}
Barbosa A.S., Bastos O.M.P., Dib L.V., Siqueira M.P., Cardozo M.L., Ferreira L.C., Chaves W.T., Fonseca A.B.M., Uchôa C.M.A. \& Amendoeira M.R.R. 2015. Gastrointestinal parasites of swine raised in different management systems in the State of Rio de Janeiro, Brazil. Pesquisa Veterinária Brasileira 35(12):941-946. Laboratório de Toxoplasmose, Instituto de Oswaldo Cruz (FioCruz), Prédio 108, sala 32/34, Avenida Brasil 4365, Manguinhos, RJ 21045-900, Brazil. E-mail: alynne.barbosa@ioc.fiocruz.br

From 2012 to 2013 were surveyed gastrointestinal parasites from pig farms located in different municpaliyies in the state of Rio de Janeiro. Fecal samples from 790 pigs were collected from the rectum on 88 family farms and 702 farms with industrial production. The samples were subjected to Faust et al., Sheather, Ritchie, Lutz and direct examination faecal techniques. The estimated parasite prevalence was $93.1 \%$ in family farms and $59.1 \%$ in industrial farms. Balantidium coli, coccidia and Entamoeba sp. were the parasites with the highest frequencies, and the male and female reproductive categories and fatteners pigs the most infected $(\mathrm{p}<0.05)$. Trophozoites of $B$. coli were most evident in stool samples from semi-solid followed by solid and diarrheal consistencies. Strongyles eggs and Trichuris suis have been detected exclusively in family farms. Ascaris suum eggs and Strongyloides ranso$m i$ showed low frequency. The high degree of parasitism, especially protozoa, indicates the need to reassess the management of pigs in both types of production.
\end{abstract}

INDEX TERMS: Gastrointestinal parasites, prevalence, pig farms, Balantidium coli, Rio de Janeiro.

RESUMO.- [Parasitos gastrintestinais de suínos criados sob diferentes sistemas de manejo no Estado do Rio de Janeiro.] De 2012 a 2013 foram pesquisados parasitos gastrintestinais de suínos de granjas localizadas em diferentes

\footnotetext{
${ }^{1}$ Received on January 14, 2015.

Accepted for publication on August 26, 2015.

${ }^{2}$ Laboratório de Toxoplasmose, Instituto de Oswaldo Cruz (Fiocruz), Prédio 108, sala 32/34, Avenida Brasil 4365, Manguinhos, Rio de Janeiro, RJ 21045-900, Brazil. E-mails: lais@hotmail.com,williantavora@hotmail. com, amendoei@ioc.fiocruz.br; *Corresponding author: alynne.barbosa@ ioc.fiocruz.br, alynnedsb@gmail.com

${ }^{3}$ Laboratório de Parasitologia, Departamento de Microbiologia e Parasitologia, Instituto de Biomédico, Universidade Federal Fluminense (UFF), Rua Professor Hernani de Mello 101, sala 212C, São Domingos, Niterói, RJ 24210-130, Brazil. E-mails: otiliobastos@gmail.com, mayaraperlingeiro@ yahoo.com.br, matheus_lcardozo@hotmail.com, claudiauchôa@vm.uff.br

${ }^{4}$ Divisão de Parasitologia, Instituto de Pesquisa de Evandro Chagas (IPEC), Instituto Oswaldo Cruz (Fiocruz), Avenida Brasil 4365, Manguinhos, Rio de Janeiro, RJ 21045-900. E-mail: luiz.ferreira@ipec.fiocruz.br

${ }^{5}$ Laboratório de Estatística, Departamento de Estatística, UFF, Rua Mário Santos Braga s/n, Niterói, RJ 24020-140, Brazil. E-mail: ggv.uff@gmail.com
}

municípios do estado do Rio de Janeiro. Amostras fecais de 790 suínos foram coletadas da ampola retal, sendo 88 de propriedades familiares e 702 de granjas com produção industrial. As amostras foram submetidas às técnicas de Faust et al., Sheather, Ritchie, Lutz e exame direto. A prevalência estimada foi de $93,1 \%$ nas granjas familiares e $59,1 \%$ nas granjas industriais. Balantidium coli, coccídios e Entamoeba $\mathrm{sp}$. foram os parasitos que apresentaram as maiores frequências, sendo as categorias machos e fêmeas reprodutoras e leitões de terminação as mais infectadas $(\mathrm{p}<0,05)$. Trofozoítas de $B$. coli foram mais evidenciados nas amostras fecais de consistências semi-sólida, seguida pelas fezes com consistências sólida e diarreica. Ovos de estrongilídeos e Trichuris suis foram detectados exclusivamente em criações familiares. Ovos de Ascaris suum e de Strongyloides ransomi apresentaram baixa frequência. 0 alto grau de parasitismo, principalmente de protozoários, indica a necessidade de reavaliação do manejo dos suínos em ambos os tipos de produção.

TERMOS DE INDEXAÇÃO: Parasitos gastrintestinais, prevalência, granjas de suínos, Balantidium coli, Rio de Janeiro. 


\section{INTRODUCTION}

Investment and research in pig farming have positioned Brazil in third and fourth place, respectively, in the ranking of world production and exports, and contributed to increased domestic supply on the world stage (Ministry of Agriculture 2013, Abipecs 2013). In this context, the states of Brazil in the Southeast (Minas Gerais, São Paulo and Rio de Janeiro) currently hold about $17 \%$ of the national herd and $21 \%$ of the industrial farms (Embrapa 2011). According to estimated data from IBGE (2012), the State of Rio de Janeiro has 155,328 heads of pigs.

In national herds, parasite incidence can determine common health problems at all stages of production, and is therefore a limiting factor in pig breeding establishments (Carregaro 2002). The main negative effects on animals are reflected in economic losses for producers, such as: reduced feed conversion, reduced fertility, low number of piglets born and weaned, low weight piglets at birth and at weaning, as well as losses relating to viscera of high condemnation rate in slaughterhouses (Bordin 1987, Nansen \& Roepstorff 1999, Roepstorff et al. 1998). In addition, pigs are considered the main reservoir of Balantidium coli and Entamoeba polecki, which can infect humans, especially farm laborers (Solaymani-Mohammadi \& Petri Jr 2006).

Studies in different countries have reported a high prevalence of gastrointestinal parasites in pigs produced mainly in intensive systems, industrial farms, with fewer parasitic frequency reports in animals produced in family systems. In France, Beloeil et al. (2003) detected nematodes, such as Trichuris suis and strongyles in five intensive production pig farms. In 3636 fecal samples from pigs reared on farms with an intensive production system in Guangdong Province, China, Weng et al. (2005) detected $47.5 \%$ of positivity for B. coli as well as, T. suis (5.7\%), Ascaris suum (5.2\%), strongyles (2.5\%) and coccidia (24.9\%). Also in China, the city of Chongqing, Lai et al. (2011) estimated the prevalence of intestinal parasites in pig breeding establishments with intensive and extensive system and is evidenced frequencies for A. suum (12.18\%), T. suis (10.13\%), Oesophagostomum spp. (10.13\%), Eimeria spp. (16.53\%), Cystoisospora suis (5.02\%), Cryptosporidium spp. (6.60\%) and cysts of B. coli (22.7\%). Uysal et al. (2009) detected with zoonotic potential parasites such as Giardia lamblia (3.7\%), Cryptosporidium spp. (8.8\%) and B. coli $(1.6 \%)$ in pig feces of different age groups in Istanbul, Turkey. Roepstorff et al. (1998) studied about 14.396 fecal samples from pigs confined in industrial farms in different Nordic countries, showing a high percentage of $A$. suum $(25-35 \%)$.

In Brazil, Nishi et al. (2000) examined pig feces in an intensive system, with 114 samples collected from farms located in Minas Gerais and 423 in São Paulo. The estimated prevalence of parasitic infections was $38.6 \%$ and $39.7 \%$, respectively. Aguiar (2009) made a parasitological survey of 130 pigs of family farms from the Federal District. B. coli has been the most frequently diagnosed (77.6\%) parasite, followed by coccidia $(71.1 \%)$, strongyles $(45.3 \%)$, Strongyloides ransomi (36.9\%), A. suum (27.6\%), T. suis (14.3\%) and Metastrongylus spp. (3.7\%). D'Alencar et al. (2006) stu- died 1.126 fecal samples from pig farms with an intensive system located in Camaragibe, Pernambuco, and obtained $0.27 \%$ to $1.6 \%$ for the incidence of helminthes and protozoa, respectively.

However, in the state of Rio de Janeiro the information on the prevalence of parasitic infections in pigs produced in different raising systems is limited. In this context, the objective of this work was to evaluate the estimated prevalence of gastrointestinal parasites of pigs in family and industrial farms in different cities in the state of Rio de Janeiro, correlating the positivity of parasites with the different categories of pigs in intensive systems and also the frequency of trophozoite B. coli, according to fecal consistency.

\section{MATERIALS AND METHODS}

The state of Rio de Janeiro is located in the eastern portion of southeastern Brazil, occupying an area of $43,780.172 \mathrm{~km}^{2}$, with 92 cities, having tropical climate with average annual temperatures of 22 to $24^{\circ} \mathrm{C}$ (IBGE 2012). Family farms from within the metropolitan and coastal lowlands region were invited to participate in the study since most family farmers (traditional) state concentrate on these areas. The industrial pig farms selected for this study are the main producers of pig in Rio de Janeiro, especially the ones located near the city of Petrópolis, which today is considered the largest producer in the state.

Nine pig farms were studied in different cities of Rio de Janeiro. From the metropolitan area: Itaboraí and Maricá; in the mountainous: Petrópolis; in a coastal lowland: Rio Bonito, Saquarema, Silva Jardim and Casimiro de Abreu and Northwest Rio: Itaperuna. All pig farms were georeferenced with GPS Garmin model Etrex and their locations in the state of Rio de Janeiro are plotted in Figure 1.

From September 2012 to September 2013 we collected 790 fecal samples, as follows: 88 from family farms in the cities of Rio Bonito (21), Araruama (7), Saquarema (12), Maricá (8), Itaboraí (12), Casimiro de Abreu (23) and Silva Jardim (5) and 702 of industrial pig farms of Petrópolis (479) and Itaperuna (223). This study was approved by the Ethics Committee on Animal (CEUA/ Fiocruz) license number LW57/12, protocol number 79/11-2. On family farms studied, the animals did not have definite breeds and remained in collective pens. Most of the farms used the semi-intensive farming system, except for the Araruama city farm that practiced extensive production. In industrial farms was used

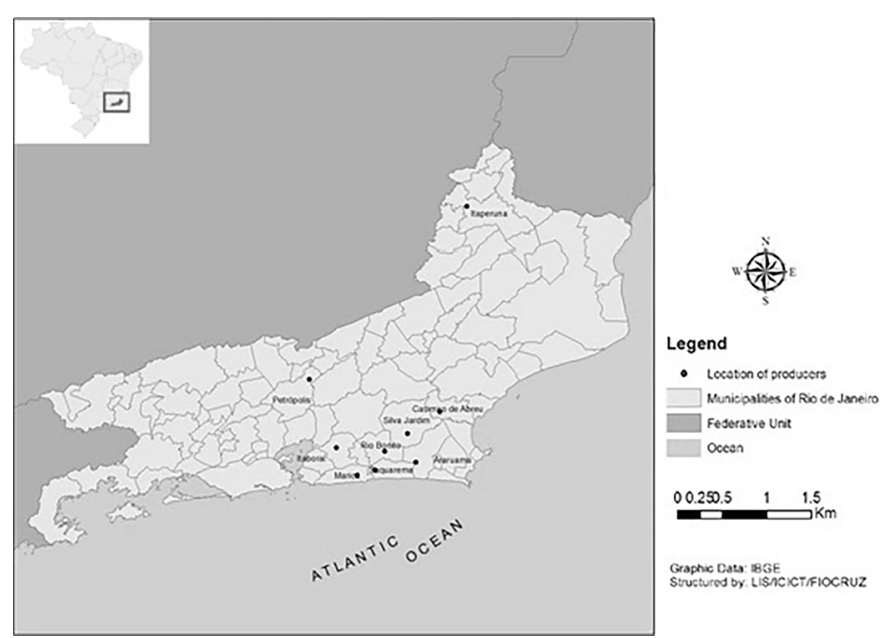

Fig.1. Location of pig farms in different municipalities of the state of Rio de Janeiro, Brazil. 
intensive system, and the pigs come from specific lineages, in Petrópolis animals belonged to TOPIG lineage Brasil ${ }^{\circledR}$ and Itaperuna the Agroceres ${ }^{\circledR}$ lineage.

In industrial pig farms, the pigs were categorized into: breeding sows (adult females): lactating, pregnant and dry sows (in reproductive rest period); female gilts (not adults who have never been inseminated), breeding males (adults), weaners piglets (weaned, 17 weeks old) and fattener pigs (18-22 weeks old). The samples were collected individually directly from the rectum with long palpation sleeves and were identified, stored in a termic container and immediately sent to the Parasitology Laboratory of the Biomedical Institute of the Federal Fluminense University for processing.

For sampling purposes, in family farms, it was decided to collect as much as possible of animals, since the number of pigs in each property was small. The collection was excluded the pregnant females and newborn piglets. In industrial farms was used the confidence of at least $80 \%$ range with $5 \%$ accuracy, with the exception of fatteners and weaners sectors in the Petrópolis pig farm where convenience sample was adopted, being collected at least 100 stool samples from each category because these sectors had more than 1,000 animals in each.

Fecal samples were categorized according to consistency as: solid, semi-solid and diarrheal being a part of this material immediately processed by direct examination. Another part of the sample was homogenized and the filtrate was aliquotted into centrifuge tubes with volume $15 \mathrm{ml}$ conical bottom for carrying out centrifugal sedimentation techniques Ritchie (1948) modified by Young et al. (1979), centrifugal flotation Faust et al. (1938); Centrifugal flotation Sheather (1923) modified by Huber et al. (2003). Part of the filtered material was left to sediment in conical bottom glasses over $24 \mathrm{~h}$ to perform the Lutz's spontaneous sedimentation technique (1919).

The reading of slides obtained in each technique and photographic documentation was performed in Olympus BX 41 optical microscope, initially at $100 \mathrm{x}$ augmentation, and then at $400 \mathrm{x}$ for confirmation if necessary. The microscope was coupled to a Samsung SDC415 digital camera with the Honestech PVR capture software. An Olympus CH30 optical microscope on a 400x augmentation with an ocular micrometer was used for morphometry of evolutionary forms of the identified parasites.

A fecal sample was considered positive when at least one evolutionary form of parasites was found (trophozoites, eggs, cysts or oocysts). The estimation of prevalence was performed dividing the number of positive samples by the total number of samples collected and these data were presented in percentages (\%). The $\mathrm{X}^{2}$ test was used with SPSS statistical software version 11.7 (SPSS ${ }^{\circledR}$, Chicago, IL) with a degree of confidence of $5 \%$ to analyze the parasite positivity of the production systems, in the categories of pigs of the industrial pig farms and also the frequency of trophozoites of Balantidium coli, in accordance to the consistency of fecal samples.

\section{RESULTS}

Of the total positive pig samples for one or more gastrointestinal parasites, 93.1\% came from the family farms and $59.1 \%$ of industrial farm, there was a significant difference $(\mathrm{P}<0.05)$ in the total amount of infected animals compared the two production systems (Table 1). Positivity for the most common parasites in family and industrial farms was respectively: Balantidium coli $(71.6 \%, 46.4 \%)$, coccidia (71.6\%, 19.2\%) and Entamoeba sp. (44.3\%, 18.6\%). The family system these protozoa had a higher estimated prevalence than in the industrialized system, with statistically significant difference between the types of production ( $\mathrm{P}$ $<0.05$ ).

Cysts of Giardia lamblia were observed only in one sample of a family farm. In familiar properties the helminthes most diagnosed were eggs of strongyles (46.6\%) and Trichuris suis $(9 \%)$ which were not detected in samples from industrial farms $(\mathrm{P}<0.05)$. Ascaris suum eggs were evidenced both in family $(4.5 \%)$ and in industry farms $(0.1 \%)$ and embryonated eggs Strongyloides ransomi detected only in samples of industrial farms $(0.6 \%)$, with no significant di-

Table 1. Gastrointestinal parasites found in swine raised in family-owned and industrial properties located in different cities of the state of Rio de Janeiro

\begin{tabular}{|c|c|c|c|c|c|c|c|c|c|c|c|}
\hline TS & Pig farms & $\begin{array}{c}\text { Pig } \\
\text { Samples }\end{array}$ & Entam $^{\mathrm{a}}$ & A. suumb & B. colia & $\operatorname{Cocc}^{\mathrm{a}}$ & G. $\operatorname{lam}^{\mathrm{b}}$ & *Stron ${ }^{\mathrm{a}}$ & T. suis ${ }^{\mathrm{a}}$ & S. $\operatorname{ran}^{\mathrm{b}}$ & $\begin{array}{c}\text { Total } \\
\text { positive }^{\mathrm{a}}\end{array}$ \\
\hline \multirow[t]{8}{*}{ Family } & A & 21 & $6(28.6 \%)$ & 0 & $9(56.2 \%)$ & $14(93.7 \%)$ & 0 & $1(6.2 \%)$ & $1(6.2 \%)$ & 0 & $16(76.1 \%)$ \\
\hline & B & 7 & $2(28.6 \%)$ & 0 & $6(85.7 \%)$ & $7(100 \%)$ & 0 & $6(85.7 \%)$ & 0 & 0 & $7(100 \%)$ \\
\hline & $\mathrm{C}$ & 12 & $5(41.7 \%)$ & 0 & $6(50 \%)$ & $12(100 \%)$ & 0 & $11(91.6 \%)$ & $5(41.6 \%)$ & 0 & $12(100 \%)$ \\
\hline & D & 8 & 0 & 0 & $7(87.5 \%)$ & $8(100 \%)$ & 0 & $5(62.5 \%)$ & 0 & 0 & $8(100 \%)$ \\
\hline & $\mathrm{E}$ & 12 & $10(83.3 \%)$ & 0 & $11(91.7 \%)$ & $11(91.7 \%)$ & 0 & $10(83.3 \%)$ & $1(8.3 \%)$ & 0 & $12(100 \%)$ \\
\hline & $\mathrm{F}$ & 23 & $15(68.2 \%)$ & 0 & $19(86.4 \%)$ & $6(27.2 \%)$ & $1(4.3 \%)$ & $4(18.1 \%)$ & 0 & 0 & $22(95.6 \%)$ \\
\hline & G & 5 & $1(20 \%)$ & $4(80 \%)$ & $5(100 \%)$ & $5(100 \%)$ & 0 & $4(80 \%)$ & $1(20 \%)$ & 0 & $5(100 \%)$ \\
\hline & Subtotal & 88 & $39(44.3 \%)$ & $4(4.5 \%)$ & $63(71.6 \%)$ & $63(71.6 \%)$ & $1(1.1 \%)$ & $41(46.6 \%)$ & $8(9 \%)$ & 0 & $82(93.1 \%)$ \\
\hline \multirow[t]{4}{*}{ Industrial } & $\mathrm{H}$ & 479 & $109(22.8 \%)$ & $1(0.20 \%)$ & $257(53.7 \%)$ & $115(24 \%)$ & 0 & 0 & 0 & $2(0.4 \%)$ & $328(68.5 \%)$ \\
\hline & I & 223 & $22(9.9 \%)$ & 0 & $69(30.9 \%)$ & $20(9 \%)$ & 0 & 0 & 0 & $2(0.9 \%)$ & $87(39 \%)$ \\
\hline & Subtotal & 702 & $131(18.6 \%)$ & $1(0.1 \%)$ & $326(46.4 \%)$ & 135(19.2\%) & 0 & 0 & 0 & $4(0.6 \%)$ & $415(59.1 \%)$ \\
\hline & Total & 790 & $170(21.5 \%)$ & $5(0.6 \%)$ & $389(49.2 \%)$ & $198(25.1 \%)$ & $1(0.1 \%)$ & $41(5.2 \%)$ & $8(1)$ & $4(0.5 \%)$ & $497(62.9 \%)$ \\
\hline
\end{tabular}

The percentages were calculated dividing the number of samples positive for parasites by the subtotal (total number or samples collected in each type of system). The percentages were calculated dividing the number of samples positive for parasites by the subtotal (total number or samples collected in each type of system). TS = type of system, Entam = Entamoeba sp., A. suum = Ascaris suum, B. coli = Balantidium coli, Cocc $=$ Coccidea, G. lam = Giardia lamblia, Estron $=$ Egg of Strongyle, . suis $=$ Trichuris suis, S. ran $=$ Strongyloides ransmoni, $\mathrm{A}=$ Rio Bonito, $\mathrm{B}=\mathrm{Araruama}, \mathrm{C}=\mathrm{Sa}-$ quarema, D = Maricá, E = Itaboraí, F = Casimiro de Abreu, G = Silva Jardim, H = Petrópolis, I = Itaperuna. * Stron = Strongyles (Eggs of Superfamily

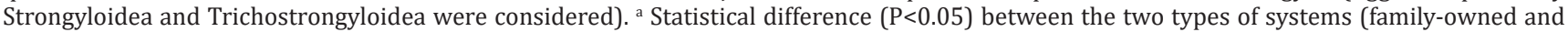
industrial farms), ${ }^{\mathrm{b}}$ There was no statistical difference $(\mathrm{P}>0.05$ ) between the two types of systems (family-owned and industrial farms). 
Table 2. Gastrointestinal parasites found in categories of swine raised in industrial farms located in different cities of the State of Rio de Janeiro

\begin{tabular}{ccccccccc}
\hline $\begin{array}{c}\text { Industrial } \\
\text { Pig farm }\end{array}$ & $\begin{array}{c}\text { Pigs } \\
\text { Categories }\end{array}$ & $\begin{array}{c}\text { Pig } \\
\text { Samples }\end{array}$ & $\begin{array}{c}\text { Entam }^{\mathrm{a}} \\
\text { H }\end{array}$ & A. suum & B. coli & Cocc $^{\mathrm{a}}$ & S. ran $^{\mathrm{b}}$ & $\begin{array}{c}\text { Total } \\
\text { positive }^{\mathrm{a}}\end{array}$ \\
\hline H & Pregnant sows & 116 & $18(15.5 \%)$ & $1(0.9 \%)$ & $72(62 \%)$ & $87(75 \%)$ & 0 & $110(94.8 \%)$ \\
I & & 33 & $1(3 \%)$ & 0 & $8(24.2 \%)$ & $3(9 \%)$ & 0 & $12(36.4 \%)$ \\
& Subtotal & 149 & $19(12.8 \%)$ & $1(0.7 \%)$ & $80(53.7 \%)$ & $90(60 \%)$ & 0 & $122(81.9 \%)$ \\
H & Lactating sows & 64 & $3(4.7 \%)$ & 0 & $2(34.4 \%)$ & $7(10.9 \%)$ & 0 & $29(45.3 \%)$ \\
I & & 11 & $1(9 \%)$ & 0 & $3(27.2 \%)$ & $7(63.6 \%)$ & 0 & $4(36.4 \%)$ \\
& Subtotal & 75 & $4(5.3 \%)$ & 0 & $25(33.3 \%)$ & $14(18.7 \%)$ & 0 & $33(44 \%)$ \\
H & Dry sows & 41 & $3(7.3 \%)$ & 0 & $21(51.2 \%)$ & $4(9.8 \%)$ & 0 & $25(61 \%)$ \\
I & & 5 & $4(80 \%)$ & 0 & $3(60 \%)$ & $1(20 \%)$ & 0 & $5(100 \%)$ \\
& Subtotal & 46 & $7(15.2 \%)$ & 0 & $24(52.12)$ & $5(10.9 \%)$ & 0 & $30(65.2 \%)$ \\
H & Gilts & 45 & $33(73.3 \%)$ & 0 & $34(75.6 \%)$ & $9(20 \%)$ & 0 & $40(88.9 \%)$ \\
I & & 6 & 0 & 0 & $3(50 \%)$ & $1(16.6 \%)$ & 0 & $4(66.6 \%)$ \\
& Subtotal & 51 & $33(64.7 \%)$ & 0 & $37(72.5 \%)$ & $10(19.6 \%)$ & 0 & $44(27.5 \%)$ \\
H & Weaners & 101 & $21(20.8 \%)$ & 0 & $34(33.7 \%)$ & $1(1 \%)$ & $1(0.99 \%)$ & $46(45.5 \%)$ \\
I & & 98 & $13(13.3 \%)$ & 0 & $20(20.4 \%)$ & $1(1 \%)$ & $1(1 \%)$ & $25(25.5 \%)$ \\
& Subtotal & 199 & $34(17.1 \%)$ & 0 & $54(27.1 \%)$ & $2(1 \%)$ & $2(1 \%)$ & $71(35.7 \%)$ \\
H & Fatteners & 104 & $28(26.9 \%)$ & 0 & $68(65.4 \%)$ & $1(0.1 \%)$ & $1(0.96 \%)$ & $73(70.2 \%)$ \\
I & & 68 & $3(4.4 \%)$ & 0 & $31(45.6 \%)$ & $5(7.4 \%)$ & $1(0.96 \%)$ & $35(51.5 \%)$ \\
& Subtotal & 172 & $30(17.4 \%)$ & 0 & $99(57.5 \%)$ & $6(3.5 \%)$ & $2(1.16 \%)$ & $108(62.8 \%)$ \\
H & Breding boars & 8 & $3(37.5 \%)$ & 0 & $8(100 \%)$ & $6(75 \%)$ & 0 & $8(100 \%)$ \\
I & & 2 & 0 & 0 & $1(50 \%)$ & $2(100 \%)$ & 0 & $2(100 \%)$ \\
& Subtotal & 10 & $3(30 \%)$ & 0 & $9(90 \%)$ & $8(80 \%)$ & 0 & $10(100 \%)$ \\
& Total & 702 & $13(18.7 \%)$ & $1(0.1 \%)$ & $326(46.4 \%)$ & $135(19.2 \%)$ & $4(0.56 \%)$ & $415(59.1 \%)$
\end{tabular}

The percentages were calculated dividing the number of samples positive for parasites by the subtotal. Entam $=E n$ tamoeba sp., A. suum = Ascaris suum; B. coli = Balantidium coli; Cocc = Coccidia; S. ransomi $=$ Strongyloides ransomi, $\mathrm{H}=$ Petrópolis, $\mathrm{I}=$ Itaperuna. ${ }^{\text {a }}$ Statistical difference $(\mathrm{P}<0.05)$ between the two types of systems (family-owned and industrial farms). ${ }^{\mathrm{b}}$ There was no statistical difference $(\mathrm{P}>0.05)$ between the two types of systems (family-owned and industrial farms).

Table 3. Rate of trophozoites of Balantidium coli found in fecal samples with solid, semi-solid and diarrheic consistencies in pig farms of different cities in the State of Rio de Janeiro

\begin{tabular}{cccccc}
\hline & & \multicolumn{3}{c}{ Consistency of feces } & Total \\
\cline { 3 - 5 } & & Solid* & Semi-solid* & Diarrheic* & \\
\hline \multirow{2}{*}{ Trophozoite B. coli } & N & $510(75.4 \%)$ & $133(19.7 \%)$ & $33(4.9 \%)$ & 676 \\
& P & $24(21.1 \%)$ & $69(60.5 \%)$ & $21(18.4 \%)$ & 114 \\
& Total & $534(67.6 \%)$ & $202(25.6 \%)$ & $54(6.8 \%)$ & 790
\end{tabular}

${ }^{*} \mathrm{P}<0.05 . \mathrm{N}=$ negative, $\mathrm{P}=$ positive.

fference between production system ( $\mathrm{P}>0.05)$ (Table 1). Monoparasite infections were found in $34.7 \%$ (274/790) and multiple parasite in $28.2 \%$ (223/790), and the associations of B. coli and Entamoeba sp. 83/223 (37.2\%) the most frequent, followed by $B$. coli and coccidia $62 / 223(27.8 \%)$ (Data not shown in table).

On farms with an industrial-type system, categories of pigs that had higher infection rates were: breeding males, followed by pregnant females (highest value found at the farm $\mathrm{H}$ ), dry sows, fattener piglets, lactating sows, weaners piglets and gilt (Table 2). There was a statistically significant difference $(\mathrm{P}<0.05)$ for categories of animals, both in total frequency parasites, as specific in the B. coli, Entamoe$b a$ sp. and coccidia, which were the most frequent parasites (Table 2).

From the 790 fecal samples of swine collected, $67.6 \%$ presented solid consistency, $25.6 \%$ semi-solid consistency and $6.8 \%$ diarrhea consistency. Trophozoites of B. coli were found by direct examination of the three categories of fecal consistencies, given that this evolutionary form was most evident in stool samples from semi-solid followed by solid and diarrheal consistences, and there was a significant difference $(\mathrm{P}<0.05)$ in the rate of diagnosis of trophozoites between the three categories of fecal consistency (Table 3).

\section{DISCUSSION}

The state of Rio de Janeiro has different pig production systems, among which stand out producers, industry type and family, also known as a traditional system. In this study it became clear the difference in positivity for gastrointestinal parasites among pigs raised under different management. The total parasitic frequency of family production was higher than the industrial. High rates of gastrointestinal parasites $(96.1 \%)$ on family farms were also observed by Aguiar (2009) in the Federal District, Brazil. Lower frequencies farms with an intensive system of Rio de Janeiro were evidenced by Nishi et al. (2000) in Minas Gerais (38.6\%) and São Paulo (39.7\%). The high parasite positivity in traditional family systems was also reported by Lai et al. (2011) in pigs of Chongqing, in China, without significant difference relating to the intensive system.

Evolutionary forms of Balantidium coli, not sporulated oocysts of coccidia and uninucleate cyst of Entamoeba sp. were the most detected in both production systems, with a significant difference among them being the most evident parasitism association between these protozoa (B. coli and Entamoeba sp., B. coli and coccidia). Results that differ from the farms of Rio de Janeiro found by Lai et al. (2011) showed that $B$. coli in traditional and industrial farming respective- 
ly, $22.1 \%$ and $23.4 \%$, with smaller frequency, without significant difference between the types of production. Indices slightly larger B. coli (47.2\%) and coccidia (24.9\%) were shown by Weng et al. (2005) in industrial intensive system farms in Guangdong Province, China.

Uninucleate cysts Entamoeba sp., in fecal samples of pigs, has been scarcely reported. Ismail et al. (2010) studied pig rural areas of Chungcheongnam-do, Korea showed a lower frequency of Entamoeba sp. (3.7\%) than those detected in the farms of Rio de Janeiro. Despite the distinction between Entamoeba polecki and E. suis being relevant, since only the first species are considered zoonotic and pathogenic for pigs, this study could not identify them because the size of the cysts present in compatible size ranges in both species (Stensvold et al. 2010). Cysts of Giardia lamblia were detected only in one sample in the family farm in this study, disagreeing with evidence by Uysal et al. (2009), that reported Giardia lamblia in 9 pigs (3.7\%) from different farms in Turkey. According Armson et al. (2009) there is still little information about the importance of giardiasis for the health of these animals.

Among the helminths, were only detected nematodes, and most evident in family farms were strongyles. It was considered in this group both eggs Strongyloidea superfamily and Trichostrongyloidea superfamily, as the same are identical, necessitating the stool culture and morphological study of the larvae to differentiate them. They were also detected Trichuris suis eggs and Ascaris suum, the latter being evidenced in both production systems no significant difference. Such helminths are important in pig farming because they cause a reduction in body weight gain, and specifically $A$. suum, for determining condemnation of the liver in slaughterhouse (Bordin, 1987).

The frequency of nematodes in industrial farms was $0.6 \%$, which was observed from one sample with eggs of A. suum and four samples with Strongyloides ransomi eggs. Similar results were found by D'Alencar et al. (2006) in Pernambuco, Brazil, which found a low frequency $(0.3 \%)$ of nematodes in 1126 pigs tested, including A. suum $(0.1 \%)$. Nishi et al. (2000) also observed low frequency, finding $3.5 \%$ of $A$. suum in Minas Gerais and $1.6 \%$ in São Paulo. Similarly, S. ransomi low frequency $(0.4 \%, 11.8 \%)$ was also evidenced by Roepstorff et al. (1998) studied 14,396 pigs of the Nordic countries.

$S$. ransomi is a little reported in studies of nematode parasites of pigs, possibly because of the need for measurement of eggs to distinguish them from superfamilies Trichostrongyloidea and Strongyloidea. Another factor that may interfere with the meeting of this parasite, resulting in a false negative, it would be bad thermal conditioning of the samples carrying the eggs hatch, a fact reported by Nansen and Roepstorff (1999).

The significant difference between frequencies: high in protozoa and low in nematodes, observed mainly in industrial farms can be attributed to routine anthelmintic, which is performed mainly in pregnant sows and fattener pigs. Typically, this antiparasitic therapy primarily operates in helminthes, with less effective for protozoa. Beloeil et al. (2003) noted that the low positivity for helminthes might be related to the parasite control practice that is routinely used in industrial production systems. According to Nishi et al. (2000) finding nematodes in livestock-intensive system, even if in low numbers, may be associated with contamination and the high resistance of some helminth eggs in the environment.

The higher parasite positivity in the family system than industrial pig farm was expected because industrial farming are generally companies that sell pigs for slaughterhouses which supply the consumer market, possessing more rigorous sanitary management, with cleaning facilities, room quarantine (remote installations where are the new animals that will be inserted in the farm) and anti-parasite control treatment routines. Already on family farms, producers invested in little or no health management, have little infrastructure (semi-confined or unconfined pigs) and animals are generally intended for producer consumption, or for small business transactions.

In this study, the highest parasitic frequencies by categories of pigs on industrial farms concentrated in animals of reproductive age as breeding boars, pregnant sows and dry sows and also in fattener piglets. Protozoa B. coli, coccidia and Entamoeba sp. were the mostly detected with more significant difference between the categories. These results agree with Weng et al. (2005) that also showed higher positivity in China in the categories of reproductive females and males.

The highest frequency of parasites in breeding animals can be explained by the fact that boars, females pregnant and dry sows, correspond to categories of pigs with greater longevity on the farm, living on average five to six years. The lifetime of animals in the pig farm may have favored their reinfection in contaminated environments. According to Weng et al. (2005) breeding categories when parasitized become reservoirs of infection to other age groups. Already, the high rate of parasites in the fattening sector, both in Petrópolis farms $(\mathrm{H})$ as of Itaperuna (I), may be related to confinement in collective pens and the constant presence of a water layer on the floor, a fact underscored by Nishi et al. (2000) associated this feature, when used inappropriately, for a source of parasite transmission.

Trophozoites of $B$. coli were diagnosed by direct examination solid consistency of stools, semi-solid and diarrheal, with a statistically significant frequency difference. This difference can be explained because this evolutionary forms has been more detected in semi-solid and diarrheal stools proportionally. This result was expected because feces of soft consistency generally occurs due to increased intestinal transit and/or intestinal lubrication facilitating the removal of fecal trophozoites. It was observed that the direct examination of this protozoan diagnosis favored because in some samples, as B. coli was only detected through this technique in some samples. In addition, there was a meeting of trophozoites in solid stool, which underscores the importance of conducting the direct examination in the diagnosis of balantidiasis in pigs. The monitoring of $B$. coli in pig herds become relevant because these animals are usually regarded as the major reservoir for human infection (Schuster, Ramirez-Avila, 2008). In addition, the balan- 
tidiasis has been mainly reported in countries of tropical and subtropical climates, like those of Rio de Janeiro.

Epidemiological comparisons at national and regional level were hampered due to lack of parasitism studies in pigs, suggesting the need for more research on this topic. In the pig farms located in different cities in the state of Rio de Janeiro showed up high frequency of gastrointestinal parasites mainly of protozoa, with lower percentages in the farms with industrial system. This result demonstrates the need to adopt individual sanitary control, taking into account the type of production, management used by the producer to the age of the animals, property location and physical structure of the farm, as well as the socioeconomic and cultural conditions owner.

Declaration.- The authors state that there is no conflict of interest in this study.

Acknowledgements.- The authors would like to thank for project support: FAPERJ (Research Support Foundation of the State of Rio de Janeiro), IOC (Oswaldo Cruz Institute), PROPPI-UFF (Dean's Office for Research Studies and Innovation of Federal Fluminense University) and PROAES-UFF (Dean's Office for Student Affairs of Federal Fluminense University).

\section{A contribuição dos autores para a publicação do artigo}

Alynne S. Barbosa: Executora e responsável por todas as etapas do estudo (doutoranda);

Laís V. Dib: $\quad$ Executora da coleta de amostras e processamento do material biológico;

Mayara P. de Siqueira: Executora da coleta de amostras e processamento do material biológico;

Matheus Cardozo: $\quad$ Executor da coleta de amostras e processamento do material biológico;

William Chaves: Executor da coleta de amostras e processamento do material biológico;

Luiz Claudio Ferreira: Supervisor e executor do trabalho de campo;

Ana B. Fonseca: Responsável pela análise estatística dos resultados;

Otilio M.P. Bastos: $\quad$ Professor orientador;

Claudia Uchôa: Professor orientador;

Maria R.R. Amendoeira: Coordenadora geral do projeto e professora orientadora.

\section{REFERENCES}

ABIPECS 2013. Relatório Anual 2012/2013. Associação Brasileira da Indústria Produtora e Exportadora de Carne Suína, São Paulo. Available in <http://www.abipecs.org.br/uploads/relatorios/relatoriosassociados/ABIPECS_relatorio_2012_pt.pdf Accessed on March 5, 2013.

Aguiar P.C. 2009. Aspectos epidemiológicos das parasitoses gastrintestinais de suínos naturalizados de criações familiares do Distrito Federal. Dissertação de Mestrado em Saúde Animal, Universidade Federal de Brasília, Brasília, DF. 100p.

Armson A., Yang R., Thompson J., Johnson J., Reidb S. \& Ryanb U.M. 2009. Giardia genotypes in pigs in Western-Australia: prevalence and association with diarrhea. Exp. Parasitol. 121:381-383.

Beloeil P.A., Chauvin C., Fablet C., Jolly J.P., Eveno E., Madec F. \& Reperant J.M. 2003. Helminth control practices and infections in growing pigs in France. Livest. Prod. Sci. 81:99-104.

Bordin E.L. 1987. Relações entre infecções por parasitas internos de suínos e o custo de alimentação: uma revisão. Hora Vet. 7:21-27.

Carregaro F.B. 2002. Parasitos gastrintestinais em suínos raça/tipo naturalizados do Distrito Federal. Monografia, Universidade de Brasília, Brasília, DF. 31p.
D’Alencar A.S., Faustino M.A.G., Sousa D.P., Lima M.M. \& Alves L.C. 2006. Infecção por helmintos e coccídios em criação de suínos de sistema confinado localizada no município de Camaragibe, PE. Ciênc. Vet. Tróp. 9:19-86.

Embrapa 2011. Distribuição espacial da produção de suínos no Brasil. Embrapa Suínos e Aves, Concórdia, SC. Accessed on September 7, 2013. Available in <http://www.cnpsa.embrapa.br/cias/index.php?option$=$ com_content\&view=article\&id=59>

Faust E.C., D’Antoni J.S., Odon V., Miller M.J., Perez C., Sawitz W., Thomen L.F., Tobie J.E. \& Walker J.H. 1938. A critical study of clinical laboratory technics for the diagnosis of protozoan cysts and helminth eggs in feces. I. Preliminary communication. Am. J. Trop. Med. 18:169-183.

Huber F., Bomfim T.C. \& Gomes R.S. 2003. Comparação da eficiência da técnica de sedimentação pelo formaldeído-eter e da técnica de centrifugo-flutuação modificada na detecção de cistos de Giardia sp. e oocistos de Cryptosporidium sp. em amostras fecais de bezerros. Revta Bras. Parasitol. Vet. 12:135-137.

IBGE 2012. Instituto Brasileiro de Geografia e Estatísticas Accessed on September 3, 2013. Available in <http://www.ibge.gov.br/estadosat/ perfil.php?sigla=rj>

Ismail H.A.H.A., Jeon H., Yu Y., Do C. \& Lee Y. 2010. Intestinal parasite infections in pigs and beef cattle in rural areas of Chungcheongnam-do, Korea. Korean J. Parasitol. 48:347-349.

Lai M., Zhou R.Q., Huang H.C. \& Hu S.J. 2011. Prevalence and risk factors associated with intestinal parasites in pigs in Chongqing, China. Res. Vet. Sci. 91:121-124.

Lutz A.O. 1919. Schistosomum mansoni and Schistomatose according to observations made in Brazil. Mem. Inst. Oswaldo Cruz. 11:121-155.

Ministério da Agricultura 2013. Produção. Accessed on: September 5, 2013. Available in <http://www. agricultura.gov.br/animal/mercado-interno/producao >

Nansen P. \& Roepstorff A. 1999. Parasitic helminths of the pig: factors influencing transmission and infection levels. Int. J. Parasitol. 29:877891.

Nishi A.M., Gennari S.M., Lisboa M.N.T.S., Silvestrim A., Caproni Jr L. \& Umehara O. 2000. Parasitas intestinais em suínos confinados nos Estados de São Paulo e Minas Gerais. Arqs Inst. Biológico, São Paulo, 67:199203.

Ritchie L.S. 1948. An ether sedimentation technique for routine stool examinations. Bull. U.S. Army Med. Dep. 8:326.

Roepstorff A., Nilsson O., Oksanenc A.B., Richter S.H., Örtenberg E., Christensson D., Martinsson K.B., Bartlett P.C., Nansen P., Eriksen L., Helle O., Nikander S. \& Larsen K. 1998. Intestinal parasites in swine in the Nordie countries: prevalence and geographical distribution. Vet. Parasitol. 76:305-319.

Sheather A.T. 1923. The detection of intestinal protozoa and monge parasites by a flotation technique. J. Comp. Pathol. 36:266-275.

Schuster F.L. \& Ramirez-Avila L. 2008. Current World status of Balantidium coli. Clin. Microbiol. Rev. 21:626-638.

Solaymani-Mohammadi S. \& Petri Jr W.A. 2004. Intestinal protozoa in wild boars (Sus scrofa) in western Iran. J. Wildl. Dis. 40:801-803.

Stensvold C.R., Lebba M. \& Clark C.G. 2010. Genetic characterisation of uninucleated cyst-producing Entamoeba spp. from ruminants. Int. J. Parasitol. 40:775-778.

Uysal H.K., Boral O., Metiner K. \& Ilgaz A. 2009. Investigation of intestinal parasites in pigs feces that are also human pathogens. Turkey Parasitol. 33:218-22.

Weng Y B., Hu Y.J., Li Y., Li B.S., Lin R.Q., Xie D.H., Gasser R.B. \& Zhu X.Q. 2005. Survey of intestinal parasites in pigs from intensive farms in Guangdong Province, People's Republic of China. Vet. Parasitol. 127:333-336.

Young K.H., Bullock S.L., Melvin D.M. \& Spruill C.L. 1979. Ethyl acetate as a aubstitute for diethyl ether in the formalin-ether sedimentation technique. J. Clin. Microbiol. 10:852-853. 